\title{
,ane \\ Quantifying Hail Damage in Crops Using Sentinel-2 Imagery
}

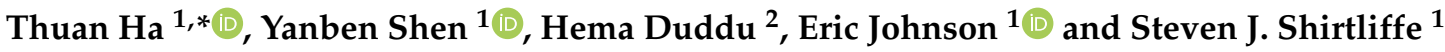 \\ 1 Department of Plant Sciences, University of Saskatchewan, Saskatoon, SK S7N 5A8, Canada; \\ yas600@mail.usask.ca (Y.S.); en.johnson@usask.ca (E.J.); steve.shirtliffe@usask.ca (S.J.S.) \\ 2 Agriculture and Agri-Food Canada, Saskatoon, SK S7N 0X2, Canada; hema.duddu@agr.gc.ca \\ * Correspondence: thuan.ha@usask.ca
}

Citation: Ha, T.; Shen, Y.; Duddu, H.; Johnson, E.; Shirtliffe, S.J.

Quantifying Hail Damage in Crops Using Sentinel-2 Imagery. Remote Sens. 2022, 14, 951. https:// doi.org/10.3390/rs14040951

Academic Editor: Xiaolin Zhu

Received: 19 January 2022

Accepted: 15 February 2022

Published: 16 February 2022

Publisher's Note: MDPI stays neutral with regard to jurisdictional claims in published maps and institutional affiliations.

Copyright: (c) 2022 by the authors. Licensee MDPI, Basel, Switzerland. This article is an open access article distributed under the terms and conditions of the Creative Commons Attribution (CC BY) license (https:// creativecommons.org/licenses/by/ $4.0 /)$.

\begin{abstract}
Hailstorms are a frequent natural weather disaster in the Canadian Prairies that can cause catastrophic damage to field crops. Assessment of damage for insurance claims requires insurance inspectors to visit individual fields and estimate damage on individual plants. This study computes temporal profiles and estimates the severity of hail damage to crops in 54 fields through the temporal analysis of vegetation indices calculated from Sentinel-2 images. The damage estimation accuracy of eight vegetative indices in different temporal analyses of delta index (pre-and post-hail differences) or area under curve (AUC) index (time profiles of index affected by hail) was compared. Hail damage was accurately quantified by using the AUC of 32 days of Normalized Difference Vegetation Indices (NDVI), Normalized Difference Water Index (NDWI), and Plant Senescence Radiation Index (PSRI). These metrics were well correlated with ground estimates of hail damage in canola $(\mathrm{r}=-0.90$, RMSE $=8.24)$, wheat $(r=-0.86$, RMSE $=12.27)$, and lentil $(r=0.80$, RMSE $=17.41)$. Thus, the timeseries changes in vegetation indices had a good correlation with ground estimates of hail damage which may allow for more accurate assessment of the extent and severity of hail damage to crop land.
\end{abstract}

Keywords: hail-to-crop damage; Sentinel-2; remote sensing; precision agriculture; time-series analysis; vegetation index

\section{Introduction}

Hailstorms are a frequent natural disaster, but a challenge to forecast, in the Canadian Prairies that can cause catastrophic damage to field crops. The specific atmospheric and geographic features of Western Canada are conducive to hailstorm activity, resulting in 'hail belt' regions [1,2]. In the warmest months of June and July, the cool dry air flowing from the Rocky Mountains encounters the hot moist surface air on the Prairies, resulting in an updraft of warm air. When the strong updrafts carrying moisture hit the high-altitude cold air, water droplets condense and freeze, creating hailstones. The Prairies represent $80 \%$ of Canadian farmland and suffer significant hail-to-crop damage and economic losses annually. The average annual agriculture loss by hail is about CAD 200 million [3]. In 2020, the Canadian Crop Hail Association (CCHA) reported the total hail insured payment on 12,100 claims was almost CAD 250 million [4]. Julian et al. [1] investigated anthropogenic climate change over North America in the present and future. The study anticipated a more frequent occurrence of large hailstorms over the Canadian Rockies and Northern Plains in the future. With such numerous hailstorms, assessment of hail damage is challenging to the conventional on-farm inspector system, which requires assessing damage on individual plants within multiple locations of each damaged field.

In North America, the hail damage to field crops is generally categorized: (1) direct plant stand loss, (2) leaf defoliation, (3) stem cut-off, and (4) grain loss [5-7]. The first damage assessment is normally conducted 7-10 days after hail occurs and involves counting plants and identifying the damage on individual plants at multiple locations within each field. The hail assessment requires careful, accurate, and reliable analysis to help farmers make decisions for replanting, harvest, and arriving at fair economic compensation for 
insurers. Conventional hail evaluation is typically used to meet the requirement, but it is considered time-consuming and labor-intensive. For these reasons, a less labor-intensive approach to estimate crop hail losses should benefit policymakers, insurance companies, and farmers.

Previous studies have found potential for using vegetation indices for estimation of hail damage in crops $[8,9]$. Hail damage causes physical defoliation and reduction in leaf chlorophyll, carotenoid, and polyphenol content [10]. Spectral indices, such as Normalized Difference Vegetation Index (NDVI), Normalized Difference Water Index (NDWI), and Plant Senescence Radiation Index (PSRI), were found to be sensitive to crop stress [11-13]. Sosa et al. [14] used five Sentinel-1 microwave indices and five Sentinel-2 multispectral indices to detect the changes in vegetation caused by hail.

Satellite remote sensing provides a planet perspective to detect the dynamic changes in the field to regional scales, which could provide an inexpensive and more reliable approach to estimate hail damage in crops. In recent years, Sentinel-2 data have gained the attention of the remote sensing community for cropland mapping due to: (1) high spatial (10 m), temporal (5 days), and spectral resolution (13 bands); (2) free and open access; and (3) available for cloud computing (Google Earth Engine, GEE) [15].

The primary remote sensing techniques commonly used in hail damage evaluation include change detection and time-series data analysis [16-18]. Change detection analyzes the variability in two or multiple images for a specific area over a distinct time period. Spectral indices before and after an event are extracted and compared. The index difference is computed; a classification method, such as thresholding, is used to classify and generate damage maps. For example, $\triangle$ NDVI from Landsat 8 imagery was used to detect crop hail damage [17]. Time-series data analysis has been used intensively in recent years for change detection. Time-series data analysis involves temporally dense monitoring of land surface dynamics over a defined period [19]. In crop damage assessment, the difference of temporal patterns of damage and non-damage (temporal integration) is computed to estimate hail damage and its severity. Sosa et al. [14] calculated the rate of index change (standard deviation) by differentiating each of the time-series obtained in each plot. The k-mean unsupervised classification on vegetation indices was used to detect the homogeneous hail damage zone on 91 plots. There was $87 \%$ damaged area strictly classified to similar degrees of damage. The area under curve (AUC) is frequently used to combine time-series disease progress into a single value and estimate disease progression's effect on crop yield [20]. Our research group [21] has used AUC to measure the flowering duration and estimate crop yield in canola. Hail damage is a spatially discrete event and causes further different crop damages. So, it should be possible to assess hail damage severity by computing the area under the curve for a time-series of vegetative indices in hail-damaged fields, whereby measuring the realistic crop damage, crop growth restriction, and crop recovery.

Despite the increasing interest in using remote sensing for hail damage mapping, the major focus was on hail-strike locations, patterns, and damaged areas. Studies on modeling hail damage severity compared with the actual crop yield loss at a field scale are limited. Previous studies have assessed hail damage severity by using the estimated biomass and predicted yield models to quantify the yield loss by hail in the simulating hailstorm field experiments [22,23].

The main objectives of the study were (1) to explore NDVI and associated temporal profiles of the dominant crop types in the hail-damaged area, (2) to estimate crop damage using series data analysis and change detection methods, (3) to identify a suitable time frame on hail event for crop damage assessment, and (4) to compare the accuracy of AUC and delta temporal analysis for hail-to-crop damage severity assessment. 


\section{Materials and Methods}

\subsection{Study Site and Data Collection}

2.1.1. Study Site

The hailstorm event occurred in an area near Assiniboia, Saskatchewan, Canada $\left(49.6328^{\circ} \mathrm{N} 105.9921^{\circ} \mathrm{W}\right)$ on 4 July 2020 . The hailstorm resulted in $28-\mathrm{mm}$ sized stones and lasted over $20 \mathrm{~min}$ during which 25 to $40 \mathrm{~mm}$ of rain also occurred. The storm track was approximately $78.8 \mathrm{~km}$ and ended near Glenbain, Saskatchewan. Our field study was conducted at the starting point of the hail event and covered an area of 3402 hectare (ha). In our study region, crops in the hailstorm-affected area consisted of canola, chickpea, durum wheat, lentil, oat, and pea. Three crops accounted for most of the area affected by the hailstorm, durum wheat, canola, and lentil (Table 1). Wheat was in shot-blade (43\%) to heading stages $(35 \%)$, canola was in the flowering stage $(62 \%)$, and lentil was in vegetative $(39 \%)$ to flowering stages (54\%) [24].

Table 1. On-field survey information for crop damage assessment.

\begin{tabular}{ccccc}
\hline Crop Types & $\begin{array}{c}\text { Damage Range } \\
\mathbf{( \% )}\end{array}$ & $\begin{array}{c}\text { Area } \\
\text { (ha) }\end{array}$ & $\begin{array}{c}\text { Area Proportion } \\
\text { (\%) }\end{array}$ & Number of Sites \\
\hline Canola & $8-72$ & 777.7 & 22.9 & 12 \\
Wheat & $4-80$ & 2299.7 & 67.6 & 36 \\
Lentil & $8-80$ & 324.5 & 9.5 & 6 \\
Total & & 3402.0 & 100 & 54 \\
\hline
\end{tabular}

\subsubsection{Hail Damage Survey}

A field survey on crop damage was conducted using a legal land survey map description of fields surveyed using Section Township Range system (reference) designate fields of individual crops that were farmed by one enterprise. Thus, the smallest crop damage assessment unit was one field of contiguously farmed land (Figure 1). The land unit (field) was normally $\frac{1}{4}$ of a section (64 ha) although the actual size ranged from 61 to 65 ha. Crop damage assessment was conducted approximately one month after the event by Municipal Hail Insurance (www.smhi.ca). The hail damage to crops was determined using proprietary methods which involve the sampling of individual plants at multiple locations and determining damage based on vegetative and reproductive loss of plant tissue.

\subsubsection{Satellite Data}

Sentinel-2 imagery courtesy of the European Space Agency was used in this study. The dataset was obtained through Google Earth Engine (GEE): ee.ImageCollection ("COPERNICUS/S2_SR"). The imagery included 12 spectral bands (from visible, near-infrared, to shortwave infrared) with different spatial resolutions (10 to $60 \mathrm{~m}$ ) with a tile size of $100 \times 100 \mathrm{~km}$. The product provides bottom of atmosphere (BOA) reflectance images, and a cloud probability band is available for shadow and cloud masking. From the region of interest, all archived images having cloud cover less than $10 \%$ and the acquisition date ranging from 1 July to 5 August 2020 (about one month after hail event) were acquired into a data collection. From the collection, pre-processing steps include cloud and shadow masking, mosaicking, index calculation, resampling $(10 \mathrm{~m})$, and extracting index values to polygons. All these steps were integrated into GEE using Java script to form a timeseries data per polygon per index. Detailed information on image band characteristics and acquisition dates used in this study is presented in Tables 2 and 3, respectively. 

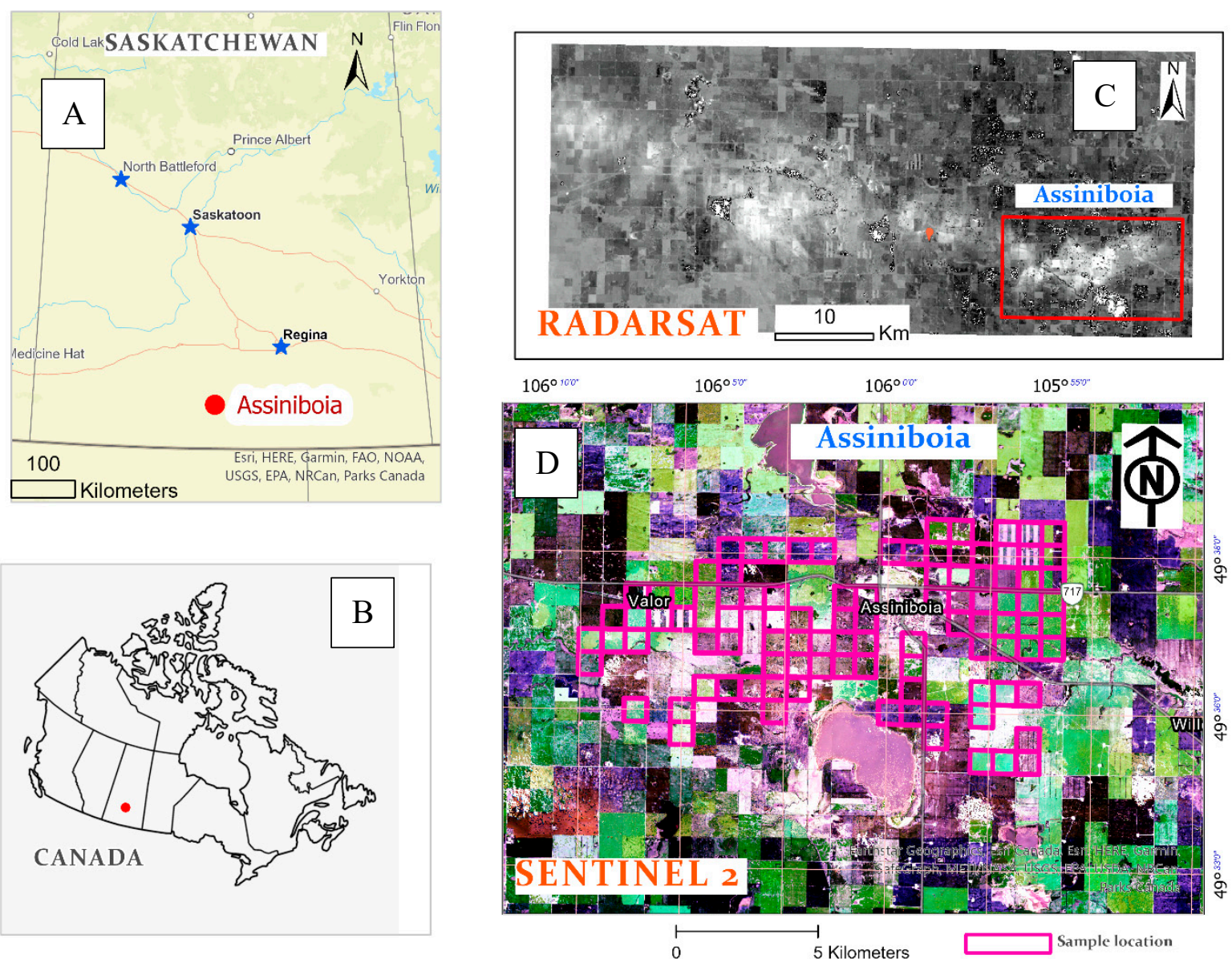

Figure 1. Study area at Assiniboia, Saskatchewan (A), Canada (B); the whole coverage area of the storm event captured by Radarsat $((\mathbf{C})$, in the bright colour) and the region of interest in the red rectangle; crop damage sample locations from selected quarter sections (D).

Table 2. Sentinel-2 data band characteristics.

\begin{tabular}{cccc}
\hline Sentinel-2 Bands & $\begin{array}{c}\text { Central Wavelength } \\
(\mathbf{n m})\end{array}$ & $\begin{array}{c}\text { Bandwidth } \\
(\mathbf{n m})\end{array}$ & $\begin{array}{c}\text { Spatial Resolution } \\
(\mathbf{m})\end{array}$ \\
\hline Band 2-Blue & 492.4 & 66 & 10 \\
Band 3-Green & 559.8 & 36 & 10 \\
Band 4-Red & 664.6 & 31 & 10 \\
Band 5-Red edge & 704.1 & 15 & 20 \\
Band 8-NIR & 832.8 & 106 & 10 \\
Band 11-SWIR & 1613.7 & 91 & 20 \\
\hline
\end{tabular}

NIR $^{1}$ : Near infrared; SWIR ${ }^{2}$ : Shortwave infrared.

Table 3. Image acquisition dates.

\begin{tabular}{cc}
\hline Date & Julian Date \\
\hline 1 July 2020 & 20183 \\
3 July 2020 & 20185 \\
6 July 2020 & 20188 \\
11 July 2020 & 20193 \\
16 July 2020 & 20198 \\
26 July 2020 & 20208 \\
28 July 2020 & 20210 \\
5 August 2020 & 20218 \\
\hline
\end{tabular}




\subsection{Methods}

All field survey data with crop type and hail damage severity (hereafter damage) and remotely sensed data from Sentinel-2 were used as inputs. The workflow to pursue our research objectives involves (1) data pre-processing of the field boundary map and remotely sensed data, (2) vegetation index extraction, (3) time-series data analysis, and (4) regression test for crop damage estimation (Figure 2).

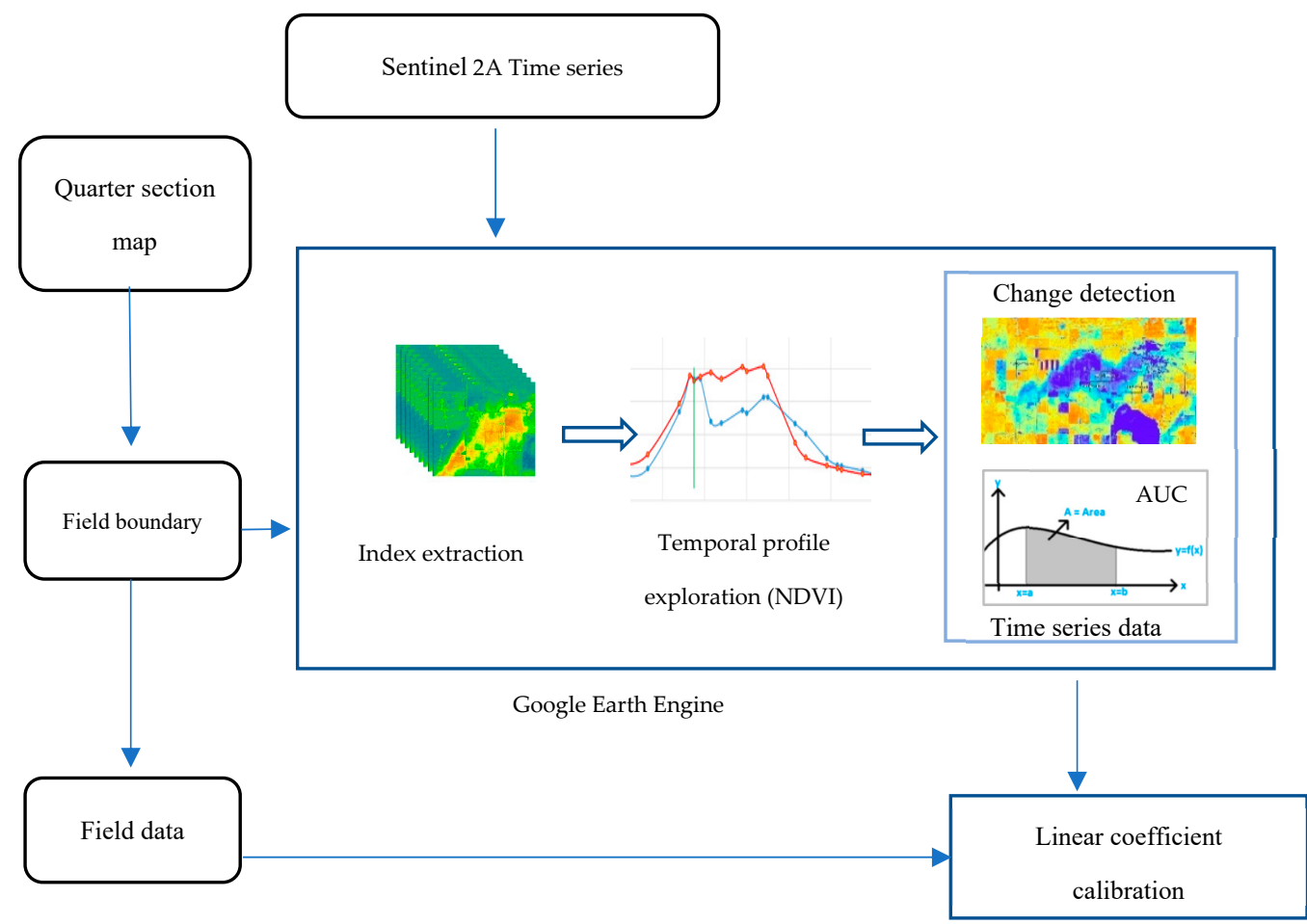

Figure 2. Flowchart of data processing and crop hail damage estimation methods using area under the curve (AUC) and change detection.

\subsubsection{Pre-Processing}

Field boundary was created using a quarter section shapefile as the basic map [25]. Information from the field survey (crop type and damage percentage) was then updated in an associated attribute table. The map editing tool of ArcGIS Pro was used to exclude non-cropland features, such as water bodies, roads, or buildings. Object features with crop types other than wheat, canola, and lentil were filtered out. Field area (ha), field code, and geometry properties ( $x$ and $y$ coordinates) were also updated using the WGS_1984_UTM_Zone_13N coordinate system. This shapefile was then uploaded into GEE and used as the region of interest for remote sensing data collection.

Pre-processing remotely sensed data involved cloud and shadow masking for a cloudless time-series dataset. Two Sentinel products (Sentinel-2 Multispectral Instrument Level2A surface reflectance (S2_SR) and Sentinel-2 Cloud Probability (or S2cloudless)) were used as input and data processing workflow was adapted from the GEE community [26]. Accordingly, the two data products were collected and joined using the acquisition index ('system: index'). Images with high cloud coverage $(60 \%)$ or pixels with high cloud probability (50\%) (the threshold values set by users) were masked out for a cloudless S2_SR collection. Since the study area is located at the edge of the image frame (or tile), two tiles may cover parts of the study area for each acquisition date (image duplication). Therefore, image mosaic by acquisition index or date was applied to merge the two image tiles into one. Additionally, space (field boundary) and time (1 July to 5 August) filters were also applied to reduce data collection time. At the end of this step, a dataset containing nine images within field boundaries was created and stored for the subsequent processing steps. 


\subsubsection{Vegetation Index Extraction}

Eight vegetative indices were used and grouped into two categories: water content and plant health to differentiate the hail in the satellite image (calculation formulas showed in Table 4). NDVI is the most well-used index in agriculture and correlates to plant nitrogen content, health, and yield [27]. Green Normalized Difference Vegetation Index (GNDVI) is similar to NDVI with a substitution of the green band for the red band [28], and the index is more sensitive to crop chlorophyll content than NDVI. It were included in crop damage assessment and yield prediction [29,30]. The Modified Soil-Adjusted Vegetation Indices (MSAVI2) use an additional parameter with red and NIR bands to address some of the limitations of NDVI when applied to areas with a high degree of exposed soil surface [31,32]. The Plant Senescence Radiation Index (PSRI) can estimate chlorophyll and was developed to evaluate the stage of leaf senescence but is also sensitive to new growing plants $[13,33]$. The Enhanced Vegetation Index (EVI) has been used in assessing canopy area and the canopy light interception of active photosynthetic radiation [34].

Indices of water content use Green, NIR, and SWIR bands. Moisture Stress Index (MSI) captures the reflectance of the water in the leaf cell and is sensitive to increasing leaf water content. Welikhe et al. [35] measured the vegetation responses of MSI to estimate soil moisture at $20 \mathrm{~cm}$ depth and mapped the spatial distribution of water during the crop-growing season. Green Normalized Difference Water Index (NDWIg) was originally developed to delineate open water features by McFeeter [36]. The index has been using for crop yield prediction, crop evapotranspiration, and water stress [37]. Similarly, Normalized Difference Water Index (NDWI) use NIR and SWIR normalized differences by Gao et al. [11]. NDWI was found better than NDWIg to discriminate the water features mixed with vegetation [38]. The mean value per field for each vegetative index was calculated on each image date and exported as an attribute table for time-series data analysis.

Table 4. Spectral indices calculated from Sentinel-2 data used in this study for crop hail damage estimation.

\begin{tabular}{|c|c|c|c|}
\hline Index & Formula & Target & Reference \\
\hline \multicolumn{4}{|l|}{ Plant Health Indices } \\
\hline Normalized Differential Vegetation Index (NDVI) & $\frac{N I R-R e d}{N I R+R e d}$ & Plant health & [27] \\
\hline $\begin{array}{l}\text { Green Normalized Difference Vegetation Index } \\
\text { (GNDVI) }\end{array}$ & $\frac{\text { NIR - Green }}{\text { NIR }+ \text { Green }}$ & Chlorophyll content & [28] \\
\hline Modified Soil Adjusted Vegetation Index (MSAVI2) & $\underline{\left(2 \times N I R+1-\operatorname{sqrt}\left((2 \times N I R+1)^{2}-8 \times(N I R-R e d)\right)\right.}$ & Uneven growth & [31] \\
\hline Plant Senescence Radiation Index (PSRI) & $\frac{\text { Red }-{ }^{2} \text { Green }}{\text { Rededge }}$ & Leaf chlorophyll & [13] \\
\hline Enhanced Vegetation Index (EVI) & $2.5 \times \frac{N I R-\text { Red }}{N I R+(6 \times \text { Red }-7.5 \times \text { Blue })+1))}$ & Canopy light interception & [39] \\
\hline \multicolumn{4}{|l|}{ Water Content Indices } \\
\hline Moisture Stress Index (MSI) & $\frac{S W I}{N I R}$ & Leaf water content & [40] \\
\hline Green Normalized Difference Water Index (NDWIg) & $\frac{\text { Green }- \text { IVIN }}{\text { Green }+ \text { NIR }}$ & Crop water content & {$[36]$} \\
\hline Normalized Difference Water Index (NDWI) & $\frac{N I R-S W I R}{N I R+S W I R}$ & Crop water content & [11] \\
\hline
\end{tabular}

\subsubsection{Crop Damage Estimation by AUC of Vegetation Index}

To access the temporal effect of hail damage on the three target crops, fields with the three different crop types (wheat, canola, and lentil) characterized by low and high damages were used to generate temporal profile plots for visualization (May to September).

Over the study area, eight image dates were collected and constructed in a time-series data. Average index values per field were extracted over time (1 July to 5 August), forming a time-series data for each field. Then, the Area Under the Curve (AUC) was calculated per index (hereafter AUC index) per field [40]. This resulted in generating a single AUC index 
using multiple input values of a specific index over a period of time per field (polygon). As in Figure 3, AUC is calculated by a definite integral between the two points ( $y=f(x)$ with $\mathrm{x}=\mathrm{a}$ and $\mathrm{x}=\mathrm{b}$ ). The relationship between crop damage and the AUC index could be positive or negative depending on the index pattern over time. For instance, the higher crop damage, the lower the AUC index of NDVI. The AUC was calculated in MATLAB (version 9.7, 2019, MathWorks, Natick, MA, USA). Overall, AUCs of 9 indices over 54 fields were calculated. Correlation coefficients $(r)$ were calculated to understand the relationship between the crop damage and time-series data (AUC).

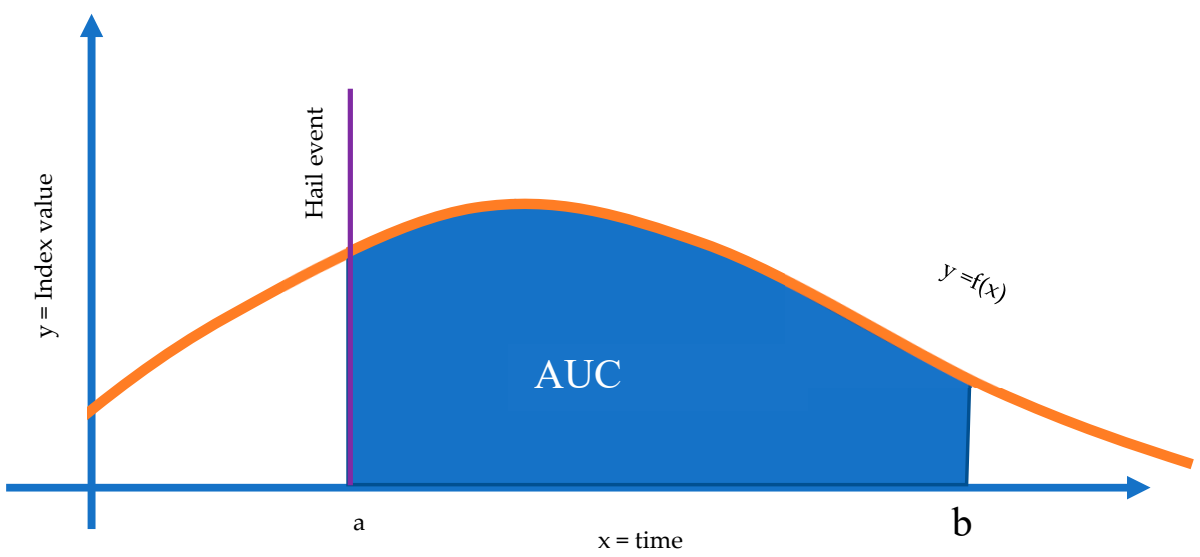

Figure 3. Area under the curve (AUC) concept for hail crop damage estimation. The $x$-axis shows timeline; the $y$-axis shows index value; the orange line is index pattern in the function of time $(y=f(x))$; a denotes the hail-event date; $a$ to $b$ defines crop damage assessment in a time frame (in days).

\subsubsection{Crop Damage Estimation by Delta Indices between the Pre- and Post-Hail}

The difference of vegetation index between pre-and post-hail is an alternative approach to assess hail-to-crop damage. Plant health and water content vegetation indices had the best prediction results of crop damage by AUC and were then selected to calculate the delta indices. In this study, NDVI and NDWI, which have been used successfully for crop damage estimation by hail, were used [17]. Crop damage estimation was based on the normalized difference between before and after index maps using the following equation:

$$
\begin{aligned}
\Delta \mathrm{NDVI} & =\frac{\mathrm{NDVI}_{\text {before }}-\mathrm{NDVI}_{\text {after }}}{\mathrm{NDVI}_{\text {before }}+\mathrm{NDVI}_{\text {after }}} \\
\Delta \mathrm{NDWI} & =\frac{\mathrm{NDWI}_{\text {before }}-\mathrm{NDWI}_{\text {after }}}{\mathrm{NDWI}_{\text {before }}+\mathrm{NDWI}_{\text {after }}}
\end{aligned}
$$

This method compared the change in vegetative index either two days (hereafter $\Delta \mathrm{NDVI}_{01-06}$ or $\Delta \mathrm{NDWI}_{01-06}$ ) or seven days (hereafter $\Delta \mathrm{NDVI}_{01-11}$ or $\Delta \mathrm{NDWI}_{01-11}$ ) following the hail event (on 4 July). For each field, the average of the damage estimation was summarized and saved. All steps were executed in Google Earth Engine. Figure 4 shows NDVI maps before (Figure 4A) and after (Figure 4B) the hailstorm event. 

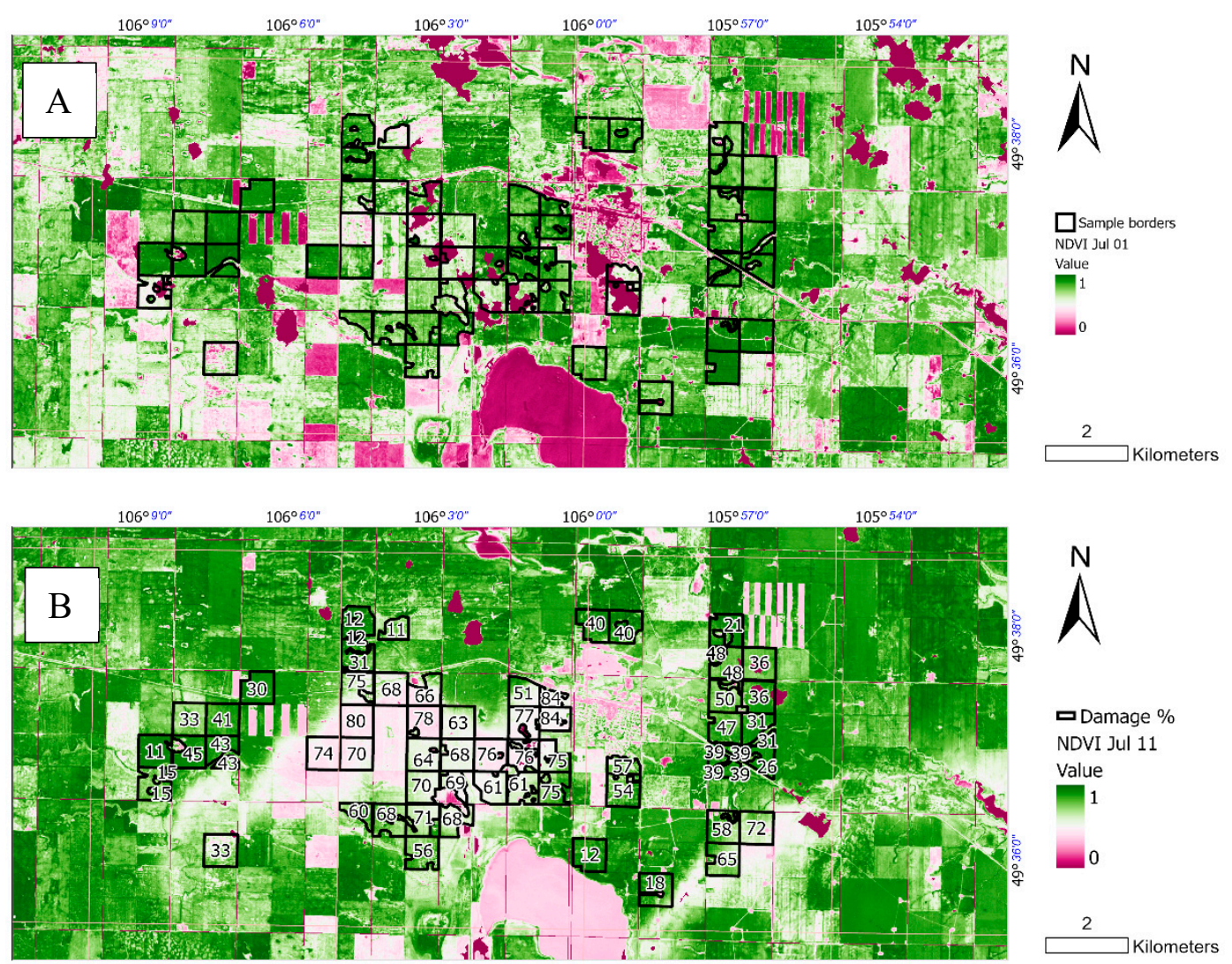

Figure 4. The satellite-based NDVI raster layers of 3 days before (A) and 7 days after the hailstorm (B) with the sample borders and crop damage labels in percentage (\%). The crop hail damage was assessed on 54 sites by an insurance survey.

\subsubsection{Validation}

Correlation coefficients ( $r$ ) and Root Mean Squared Error (RMSE) were used to validate the assessment quality between crop damages observed from fields and the damages estimated from remote sensing data. Correlation coefficients (r) ranges from 0 to 1 and indicates how well the data fit the goodness of fit line. It is also known as the coefficient of determination, and the value was calculated by Equation (3). RMSE is an absolute measure of fit indicating the error between the observed and the predicted data points. RMSE is calculated by Equation (4), and the lower value indicates the better fit.

$$
\begin{gathered}
\mathrm{r}=\frac{n\left(\sum(x y)-\left(\sum x\right)\left(\sum \mathrm{y}\right)\right)}{\left.\sqrt{\left[n \sum x^{2}-\left(\sum x\right)^{2}\right]}\left[n \sum y^{2}-\left(\sum y\right)^{2}\right)\right]} \\
\text { RMSE }=\frac{\sum_{i=1}^{n}\left(y_{i}-x_{i}\right)^{2}}{n}
\end{gathered}
$$

$x$ : observed value; $y$ : associated predicted value; $n:$ the number of observations.

$i$ : simulation index with an increment of 1 .

For each crop type, the index with the highest $r$ and lowest RMSE was used and presented graphically. The equation was also used to generate a thematic map of hail damage.

\section{Results}

\subsection{Crop Damage and Temporal Profiles}

The crop reflectance affected by the severe hailstorm identified differences in vegetative index reduction and recovery rates between crop species. Figure 5 illustrates NDVI 
temporal profiles of high damaged fields in canola $(72 \%)$, wheat $(84 \%)$, and lentil $(80 \%)$ compared to low damaged areas (4-11\%). The severe damage in crops caused the apparent reduction in the NDVI temporal profiles. The NDVI trajectory of the high damaged fields dropped dramatically after the hail event and then started to recover (after $\sim 10$ days). By contrast, we found a slight drop on the day of the hailstorm, and crops recovered fast in the NDVI trajectory in the low-damage fields (Figure 5).

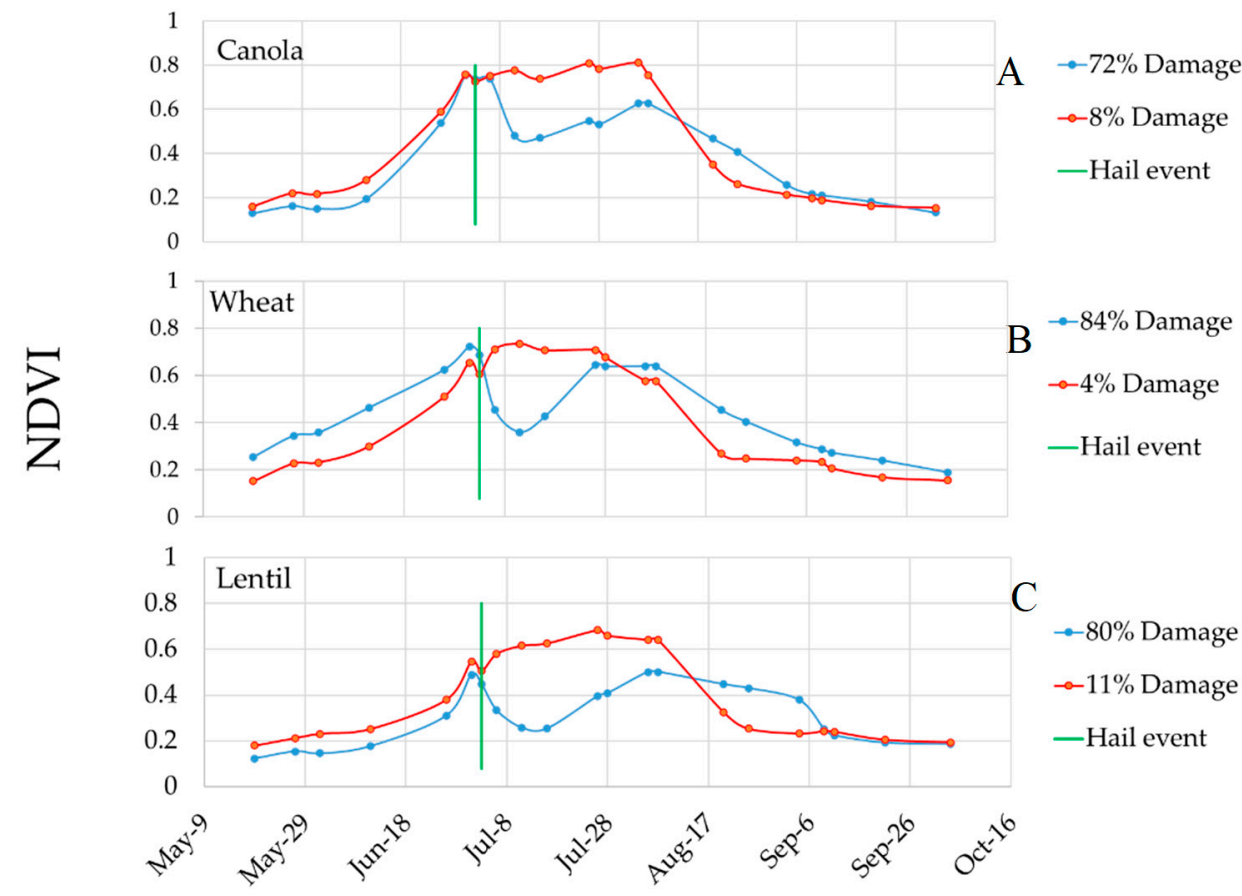

Date in 2020

Figure 5. An example of NDVI temporal profiles shows two fields of the low (red) and high damaged area (blue) on (A) canola, (B) wheats, and (C) lentils throughout the growing season. The legend of figures represented the crop damaged assessed by the insurance inspector, for example $72 \%$ damage is the crop damage assessed by ground measurements from individual field.

Canola and wheats experienced a longer damaging effect than lentils, where the lowest NDVI occurred on the eighth day following hail. In comparison, the lowest NDVI on canola and wheat was recorded on day thirteen. Furthermore, the crops also differed in recovery rate. The crossing point after the hail between the high and low damage NDVI trends in each crop indicates plant recovery, with wheat vegetation recovering faster than canola and lentil crops. Wheat recovered approximately 24 days after the hail, whereas recovery of canola and lentil occurred 32 days after the hail. Figure 5 shows examples of NDVI temporal profile on canola, wheat, and lentil. The figure suggests that one month after the hail event could be the suitable time frame for time-series data collection, in which the significant damage due to a hail event can be thoroughly captured.

\subsection{Crop Damage Estimation Using AUC Approach}

This section presents the hail damage estimation by AUC of eight individual vegetation indices in two different time windows, 32-day data, and 12-day data. Using different datasets on three crops, different hail damage estimators are presented in Tables 5 and 6. 
Table 5. The correlation coefficient (r) between crop damage (\%) and area under curve (AUC) of vegetation indices, that the total area of AUC occurring 32 days after the hail, in canola, wheat, lentil fields.

\begin{tabular}{ccccccc}
\hline \multirow{2}{*}{$\begin{array}{c}\text { Indices for AUC } \\
\text { (32 Days) }\end{array}$} & \multicolumn{2}{c}{ Canola } & \multicolumn{2}{c}{ Wheat } & \multicolumn{2}{c}{ Lentil } \\
\cline { 2 - 7 } & $\mathbf{r}$ & RMSE & $\mathbf{r}$ & RMSE & $\mathbf{r}$ & RMSE \\
\hline EVI & -0.86 & 9.70 & -0.83 & 13.25 & -0.78 & 18.04 \\
GNDVI & -0.89 & 8.69 & -0.85 & 12.74 & -0.76 & 19.05 \\
MSAVI & -0.88 & 8.76 & -0.81 & 14.26 & -0.79 & 17.58 \\
MSI & 0.88 & 8.88 & 0.85 & 12.79 & 0.78 & 18.21 \\
NDVI & -0.90 & 8.24 & -0.82 & 13.63 & -0.78 & 18.20 \\
NDWIg & 0.89 & 8.69 & 0.85 & 12.74 & 0.76 & 19.05 \\
NDWI & -0.89 & 8.57 & -0.86 & 12.27 & -0.76 & 18.62 \\
PSRI & 0.86 & 9.52 & 0.81 & 14.17 & 0.80 & 17.41 \\
\hline
\end{tabular}

Table 6. The correlation coefficient between crop damage (\%) and area under curve (AUC) of vegetation indices, that the total area of AUC occurring 12 days after the hail, in canola, wheat, and lentil fields.

\begin{tabular}{ccccccc}
\hline \multirow{2}{*}{$\begin{array}{c}\text { Indices for AUC } \\
\text { (12-Day) }\end{array}$} & \multicolumn{2}{c}{ Canola } & \multicolumn{2}{c}{ Wheat } & \multicolumn{2}{c}{ Lentil } \\
\cline { 2 - 7 } & $\mathbf{r}$ & RMSE & $\mathbf{r}$ & RMSE & $\mathbf{r}$ & RMSE \\
\hline EVI & -0.45 & 16.81 & -0.79 & 14.57 & -0.69 & 21.01 \\
GNDVI & -0.68 & 13.88 & -0.81 & 13.95 & -0.68 & 21.25 \\
MSAVI & -0.68 & 13.80 & -0.77 & 15.18 & -0.71 & 20.24 \\
MSI & 0.60 & 15.09 & 0.76 & 15.53 & 0.66 & 21.60 \\
NDVI & -0.68 & 13.83 & -0.79 & 14.73 & -0.69 & 20.93 \\
NDWIg & 0.68 & 13.88 & 0.81 & 13.95 & 0.68 & 21.25 \\
NDWI & -0.60 & 15.09 & -0.77 & 15.28 & -0.65 & 22.01 \\
PSRI & 0.56 & 15.54 & 0.77 & 15.20 & 0.74 & 19.55 \\
\hline
\end{tabular}

Correlation coefficients (r) between AUC and crop damage on the 32-day data (Table 5), show that the maximum $r$ and the least RMSE varied with crop type and indices. Although NDVI was the best estimator for canola damage $(r=-0.90$ and RMSE $=8.24)$, NDWI was the best estimator for hail damage on wheat $(r=-0.86$ and RMSE $=12.27)$. The best estimator for lentil damage was PSRI ( $r=0.80$ and RMSE $=17.41)$. The best linear relationship between crop damage and selected AUC indices, as well as the prediction equations for each crop are shown in Figure 6.
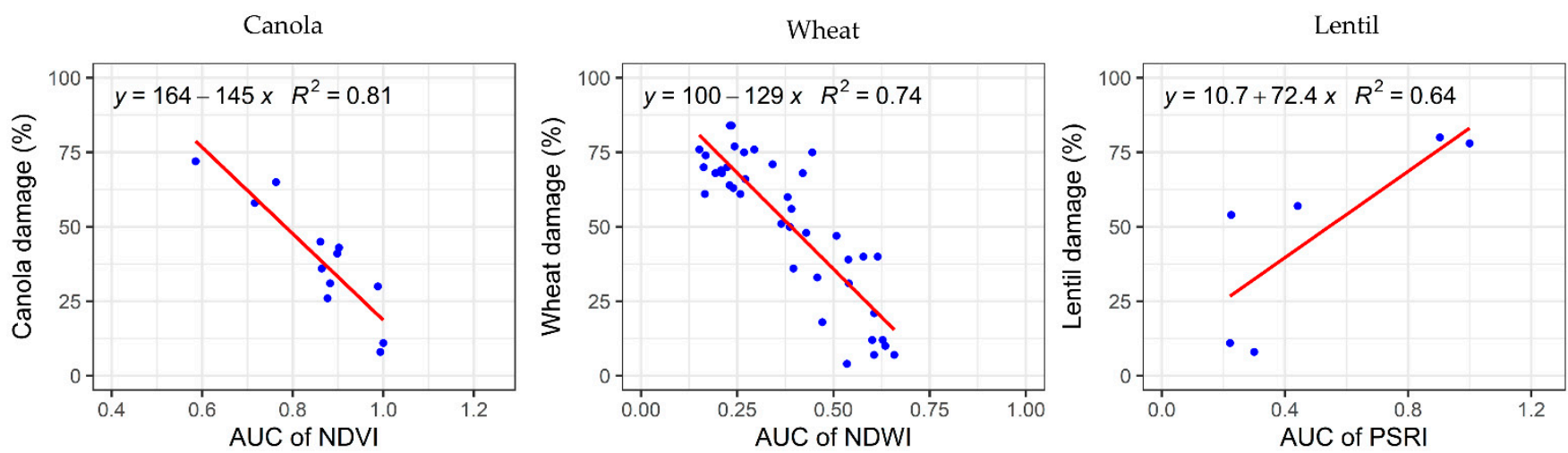

Figure 6. Correlation of the measured crop damage and the AUC of 32-day data for selected indices on canola (left), wheat (center), and lentil (right).

The capability of these models depends on many factors, including the time window for data collection. In this case, a shorter time window (12 days) was used to compare 
with the previous time window (32 days). The same indices were calculated, and the correlation coefficient between 12-day AUC and crop damage (\%) was computed (Table 6). On canola, the greatest correlation of -0.68 can be achieved from some AUC indices (GNDVI, MSAVI, DNVI, and DNWIg), while the lowest associated RMSE for the crop is with MSAVI (13.80). On wheat, GNDVI and NDWIg estimators give the greatest correlation $(-0.81)$ and RMSE (13.95). PSRI is the best estimator for lentil damage with $r$ and RMSE of -0.74 and 19.55, respectively. Compared to the 32-day AUC assessment (Table 5), the 12-day AUC assessment (Table 6) resulted in lower $r$ and higher RMSE values.

Overall, hail crop damage and AUC indices can be described by a linear relationship. The 32-day dataset provides a stronger relationship between the crop damage and AUC indices on each crop. NDVI, NDWI, and PSRI are relatively greater for hail damage estimation compared with other indices in canola, wheat, and lentil, respectively. Figure 7 illustrates crop damage measured versus predicted.

Canola

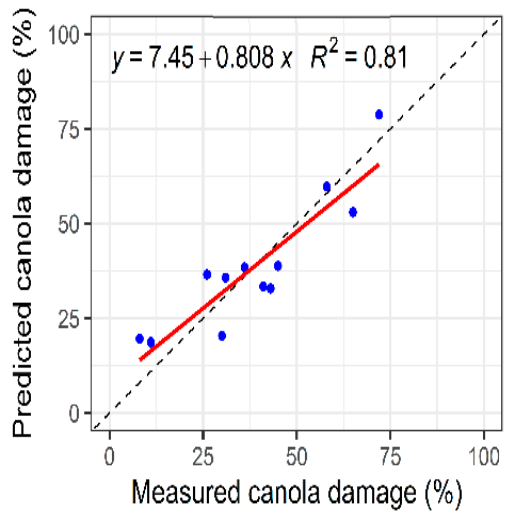

Wheat

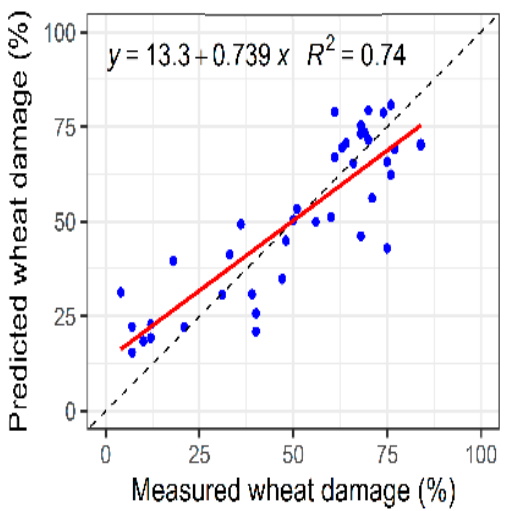

Lentil

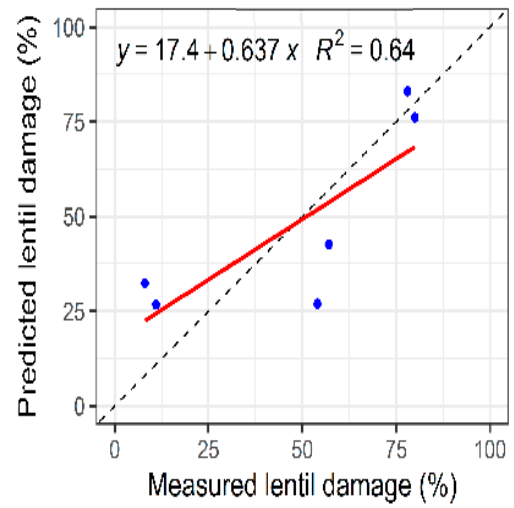

Figure 7. Correlation of the measured crop damage and predicted crop damage using the AUC of 32-day data on canola (left), wheat (center), and lentil (right).

\subsection{Crop Damage Estimation Using Delta Indices}

The delta index, the difference before and after the hail event, was calculated for hail damage estimation. Table 7 shows the two metrics ( $r$ and RMSE) that assess the estimation accuracy. In Table 7, the column name is denoted as the index difference between the dates (e.g., $\triangle \mathrm{NDVI}_{01-06}=$ before and 2 days after hail, and $\triangle \mathrm{NDVI}_{01-11}=$ before and 7 days after hail). In all crops, the 12-day delta indices had a higher $r$ and lower RMSE values than the 7-day delta indices. The NDVI had a more precise damage assessment than the NDWI. The $\triangle \mathrm{NDVI}_{01-11}$ is the best estimator for canola damage with $\mathrm{r}$ and RMSE of 0.89 and 8.44, respectively. In contrast, $\triangle \mathrm{NDWI}_{01-11}$ has $\mathrm{r}=0.83$ and $\mathrm{RMSE}=10.03$ for canola. On wheat and lentil, the difference of estimation RMSE between two indices is greater, where NDVI had a $7 \%$ lower RMSE than NDWI in both crops. $\triangle$ NDVI can be a robust approach for crop damage assessment if limited satellite imagery is available after a hail event. As shown in Figure 8, highly damaged regions can be captured (red region) using 7-day $\Delta$ NDVI, but 12-day $\triangle$ NDVI shows a higher potential of capturing the total damage than in the lower right corner of the map, in which Figure $8 \mathrm{~B}$ shows a new red region. This could be delayed or longer-term impacts of the hail damage. Additionally, the figures reveal that the change detection approach may not fully capture low damage. 
Table 7. The correlation coefficient and RMSE between crop damage (\%) and the delta indices, that was the index difference of before and after the hail in the 7-day and 12-day datasets in canola, wheat, and lentil fields.

\begin{tabular}{ccccccc}
\hline \multirow{2}{*}{$\begin{array}{c}\text { Delta } \\
\text { Index }\end{array}$} & \multicolumn{2}{c}{ Canola } & \multicolumn{2}{c}{ Wheat } & \multicolumn{2}{c}{ Lentil } \\
\cline { 2 - 7 } & $\mathbf{r}$ & RMSE & r & RMSE & r & RMSE \\
\hline$\Delta$ NDVI $_{01-06}$ & 0.38 & 16.8 & 0.76 & 15.49 & 0.7 & 20.5 \\
$\Delta$ NDVI $_{01-11}$ & 0.89 & 8.44 & 0.77 & 15.24 & 0.77 & 18.44 \\
$\Delta$ NDWI $_{01-06}$ & 0.13 & 18 & -0.11 & 23.89 & 0.24 & 28.08 \\
$\Delta$ NDWI $_{01-11}$ & 0.83 & 10.03 & 0.35 & 22.52 & 0.47 & 25.58 \\
\hline
\end{tabular}

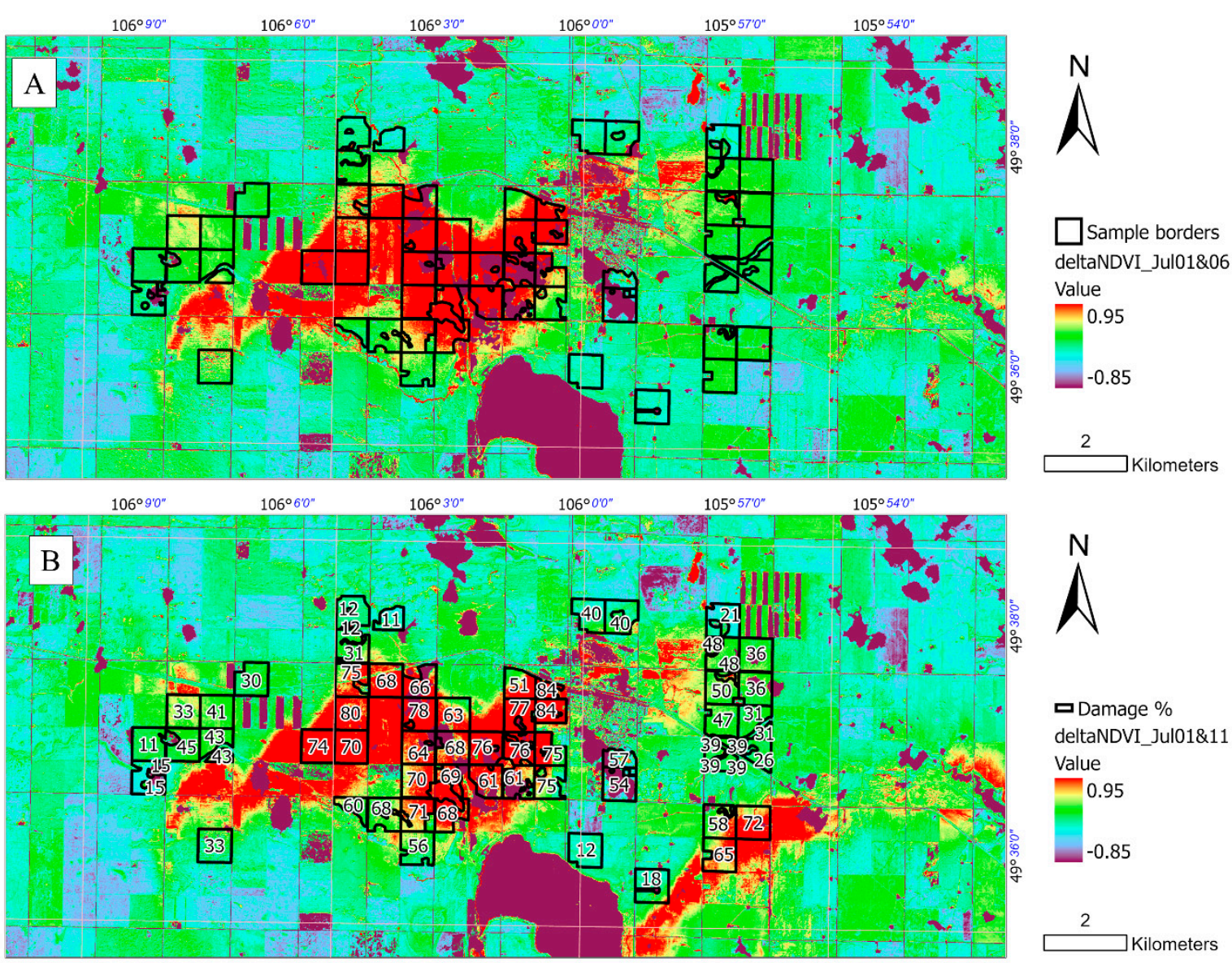

Figure 8. The raster layers by 7-day $\Delta$ NDVI (A) and 12-day $\Delta$ NDVI (B) of the study area with field measured crop damage (\%). The labelled value in each grid was the crop damage $\%$ manually assessed by insurance survey.

Comparing the hail-to-crop damage assessments by AUC and delta approaches in three crops, the 32-day AUC had the highest $r$ and lowest RMSE, followed by the 12-day delta index, 12-day AUC, and 7-day delta index. A trend showed that the AUC approach had less vegetation index impact than the delta approach. The difference of RMSE amongst eight indices by 12-day AUC assessment is 3\%, $1.5 \%$, and $2.5 \%$ in canola, wheat, and lentil, respectively. The 32-day AUC had a more subtle difference amongst the vegetation indices, which was $1.5 \%, 2 \%$, and 1.6\% RMSE difference in canola, wheat, and lentil. In comparison, the estimation accuracy of the delta index varied highly with the vegetation indices in each crop. The difference of RMSE between 12-day NDVI and 12-day NDWI is 1.5\%, 7\%, and $7 \%$ in canola, wheat, and lentil, respectively. 


\section{Discussion}

The current study used Sentinel-2 to estimate hail damage in 54 fields (3402 hectares) of canola, wheat, and lentil crops near Assiniboia (49.6328 $\left.8^{\circ} \mathrm{N} 105.9921^{\circ} \mathrm{W}\right)$ on 4 July 2020. The crop damage due to hail was variable among the three crops. The effect of hail on vegetation indices was longer in canola and wheat compared to lentil. Wheat was found to recover at 33 days after the hail; whereas canola and lentil showed a delayed recovery.

Differential crop tolerance could be the reason for varying vegetation index correlation between crops. The correlation of the vegetative indices and crop damage showed no optimal vegetative index that best estimated all hail-crop damage with NDVI, NDWI, and PSRI all having the greatest $r$ and the lowest RMSE in canola, wheat, and lentil, respectively. All vegetation indices use NIR-reflectance, which has been reported to be highly sensitive to the changes in the canopy structure and surface wetness due to hailstorm [41].

It is interesting, though perhaps not unexpected, that the mesophyll in the leaf structure is sensitive to hail. Both the NDWI and PSRI reflect the changes of the mesophyll in the plant leaf. PSRI tracks the carotenoid to chlorophyll ratio in plants [13]. In the plant leaves, carotenoid absorbs the blue-green to green wavelengths; although chlorophyll absorbs blue and red wavelengths. Since the leaf defoliation or scarred leaves by hail reduced the chlorophyll absorption of blue and red wavelengths, the ratio of carotenoid to chlorophyll in the chloroplast in the mesophyll increased; the PRSI would be raised after hail [42]. Hail also affects the water content of the spongy mesophyll, which is the site of gaseous exchange. Tartachnyk et al. [43] found that the stomata in the leaf closed during hail and remained closed for several hours, which further decreased water evapotranspiration rate. Araki et al. [44] showed that rice had sharply reduced $\mathrm{CO}_{2}$ exchange rate and mesophyll conductance in a flooded environment, and inhibited gas exchange resulted in high water content in the spongy mesophyll. The amount of water available in the internal leaf structure essentially controls the spectral reflectance in the SWIR interval of the electromagnetic spectrum, and SWIR reflectance is negatively related to leaf water content [45]. Therefore, the NDWI index increased as hail appeared, and the leaf stomata remained closed in plants that were highly damaged.

NDVI has been used in previous hail damage assessments using remote sensing $[17,46,47]$. The index is sensitive to plant health and is used to identify vegetation stress. Ref. [8] detected hail areas by: (1) classifying the anomaly pixels in the NDVI layer compared to the background and (2) passing them through kernel filters of the histogram to determine damaged or undamaged areas. However, NDVI is general to plant health; thus, confounding factors, such as flooding stress, leaf damage by plant disease, nutrient deficiency, and others could influence this index [48]. Moreover, NDVI may not be suitable for hail occurring near crop maturity.

Several studies have used methods such as quantifying the change of indices between pre- and post-hail or undamaged vs. damaged area to map the hailed area and separated different damage severity classes $[41,49,50]$. Zhao et al. [46] calculated the delta indices of pre- and post-hailstorm NDVI from HJ-1 multispectral images $(30 \mathrm{~m})$ to map hailed areas and, subsequently, categorized the damage into broad classifications of serious, moderate, and light, with a Kappa coefficient $(\kappa)$ of 0.78 . Choudhary [41] calculated the percentages changes in NDVI and Normalized Difference Tillage Index (NDTI) between pre- and posthail and estimated the affected area to five damage severity classes with an accuracy of $86.7 \%$. Our study calculated the delta NDVI from a similar calculation but computed a finer level of damage severity with a coefficient correlation of $0.77 \sim 0.89$. Additionally, the 12-day $\triangle$ NDVI indices also showed more accurate estimation than the 12-day AUC in canola and lentils. Corresponding to the fact that the canola and lentil did not recover as rapidly as wheat, the delta index was useful to assess the direct hail damage.

The comparison between the different hail damage approaches provided some interesting points. The present study calculated the AUC of the changed vegetative indices to estimate the hail severity. The crop damage estimation showed that the 32-day AUC had the highest $r$ and lowest RMSE compared with the 12-day AUC, 12-day delta index, 
and 7-day delta index. The protracted AUC analysis captures both the direct damage and plant recovery in the temporal profile; in contrast, the delta approach only measured the direct damage. Another relative improvement of the AUC approach is fitting various vegetation indices. The difference of RMSE amongst the vegetation indices in the 12-day AUC assessment is minor compared to the 12-day delta assessment. Hence, the AUC approach's estimation accuracy varies less with the vegetation indices.

Instead of comparing the plant reflectance variation by hail, another hail damage assessment compares the estimated plant biomass and yield with the potential yield from the previous years. Gobbo et al. [51] estimated the biomass and yields in 90 hectares of haildamaged corn with a precise $-4.9 \sim 3.4 \%$ difference compared to the insurance company's estimates. The author found the spatial variability within the field confounded the model and underestimated the actual biomass by $15.1 \%$. The predicted yield model could only evaluate severe damage (no grain production), whereas the yield loss for moderate and low damage could not be estimated in the large-scale fields ( 8574 hectares) [46]. The results of the study showed that changes in vegetation indices had a reasonably good correlation with crop inspector assessments. We believe that the ground survey from an insurance inspector is still essential and, when combined with index-based methodologies, more accurate estimations are possible.

We think that the ground survey from an insurance inspector is still essential for monitoring crop growth stages, evaluating potential yield, and providing aid to farming distress. The crop-damage assessment by satellite-based imagery can assist inspectors having quick overview on damage extent, as well as severity. Suitable vegetation indices explored from this study could support decision making in locating survey sites. Combining ground surveys with satellite imagery techniques makes more accurate and timely compensation possible.

Although crop damage by hail can be assessed, the study still has some limitations. First, the sample size is small, especially on lentil (six data points). As field data were collected from a single hail event, hail event time associated with crop growing stage has not been taken into consideration. Secondly, satellite data were collected from one source (Sentinel-2), so spatial and temporal resolution imagery can still be increased; environmental factors that contributed to the development of crops over time have not been included. Therefore, further research should focus on field data collection so that more sophisticated models, such as machine learning, can be used. This is possible as field data collection on crop damage by hail is conducted annually by the Municipal Hail Insurance. More satellite data sources, such as Sentinel-1, PlanetScope, Landsat, will be included to enhance data quality, as well as prediction power. Some satellite-based data on precipitation, temperature, soil moisture, evapotranspiration will be included so that damage prediction on a larger spatial scale is possible.

\section{Conclusions}

This study explored the capability of using Sentinel-2 data within a cloud computing platform for field crops damaged by a hailstorm. The hail damage on canola, wheat, and lentil over time can be monitored using Sentinel-2 time-series data. The temporal profiles of NDVI show that crop damaged by hail recovered after about one month. The area under the curve one-month dataset could accurately quantify the hail-affected crop with direct damage and plant recovery without obstructiveness of cloud cover. The 32-day AUC of NDVI, NDWI, and PSRI were well correlated with ground estimates of hail damage in canola $(r=-0.90$, RMSE $=8.24)$, wheat $(r=-0.86$, RMSE $=12.27)$, and lentil $(r=0.80$, RMSE $=17.41$ ). In comparison, the delta approach is robust and comparable to AUC approach. Still, it could be constrained or susceptible to the availability of the free cloud images over broader areas after a hail event. The cloud computing system of Google Earth Engine allows for retrieval and processing time-series data of cloud mask indices from Sentinel-2 without difficulty. It is expected that the outcomes from this study will allow companies to provide more reliable information on hail damage to farmers and the extent 
of the damaged area. As the data were collected from a single hailstorm event with a limited number of investigated fields, future studies are necessary to validate the proposed methodology over a larger area using multiple crop species at different growing stages.

Author Contributions: Conceptualization, T.H.; methodology, T.H.; software, T.H.; validation, T.H.; formal analysis, T.H.; investigation, T.H.; resources, T.H., Y.S.; data curation, Y.S., T.H.; writingoriginal draft preparation, Y.S., T.H.; writing—review and editing Y.S., T.H., H.D., E.J., S.J.S.; supervision, S.J.S.; project administration, S.J.S.; funding acquisition, S.J.S. All authors have read and agreed to the published version of the manuscript.

Funding: This research was funded by Organic Science Cluster (OSCI).

Data Availability Statement: Data available on request due to restrictions of privacy.

Acknowledgments: The hail damage data were kindly made available by Darryl Tiefenbach of the Municipal Hail Insurance, Canada (www.smhi.ca).

Conflicts of Interest: The authors declare no conflict of interest. The funders had no role in the design of the study; in the collection, analyses, or interpretation of data; in the writing of the manuscript, or in the decision to publish the results.

$\begin{array}{ll}\text { Abbreviations } \\ \text { AUC } & \text { Area under curve } \\ \text { BOA } & \text { Bottom of atmosphere } \\ \text { CAD } & \text { Canadian dollar } \\ \text { CCHA } & \text { Canadian Crop Hail Association } \\ \text { R } & \text { Correlation coefficients } \\ \text { EVI } & \text { Enhanced Vegetation Index } \\ \text { GEE } & \text { Google Earth Engine } \\ \text { GNDVI } & \text { Green Normalized Difference Vegetation } \\ \text { MSAVI2 } & \text { Modified Soil-Adjusted Vegetation Indices } \\ \text { MSI } & \text { Moisture Stress Index } \\ \text { NIR } & \text { Near infrared } \\ \text { NDTI } & \text { Normalized Difference Tillage Index } \\ \text { NDVI } & \text { Normalized difference vegetation indices } \\ \text { NDWIg } & \text { Green Normalized difference water index } \\ \text { NDWI } & \text { Normalized difference water index } \\ \text { PSRI } & \text { Plant senescence radiation index } \\ \text { RMSE } & \text { Root Mean Squared Error } \\ \text { SWIR } & \text { Shortwave infrared } \\ \text { Ha } & \text { Hectare }\end{array}$

\section{References}

1. Brimelow, J.C.; Burrows, W.R.; Hanesiak, J.M. The changing hail threat over North America in response to anthropogenic climate change. Nat. Clim. Chang. 2017, 7, 516-522. [CrossRef]

2. Sills, D.M.L.; Joe, P.I. From Pioneers to Practitioners: A Short History of Severe Thunderstorm Research and Forecasting in Canada. Atmos. Ocean 2019, 57, 249-261. [CrossRef]

3. Lozowski, E.P. Hail. Available online: https://www.thecanadianencyclopedia.ca/en/article/hail (accessed on 8 July 2021).

4. CCHA. CCHA Reports Near-Record Claims in 2020; CCHA: Deephaven, MI, USA, 2020; Available online: https:// cropinsuranceincanada.org/news/news/ (accessed on 12 December 2021).

5. USDA. Small Grains Adjustment Standards; USDA: Washington, DC, USA; FCIC: Washington, DC, USA, 2010.

6. USDA. Corn Loss Adjustment Standards Handbook; USDA: Washington, DC, USA; FCIC: Washington, DC, USA, 2019.

7. USDA. Soybean Loss Adjustment Standards; USDA: Washington, DC, USA; FCIC: Washington, DC, USA, 2019.

8. Bell, J.R.; Molthan, A.L. Evaluation of Approaches to Identifying Hail Damage to Crop Vegetation Using Satellite Imagery. J. Oper. Meteorol. 2016, 4, 142-159. [CrossRef]

9. Chandler, O.; Young, F.R.; Apan, A. Assessment of hail damage to crops using satellite imagery and hand held hyperspectral data. In Proceedings of the 12th Australasian Remote Sensing and Photogrammetry Conference, Fremantle, Australia, 18-22 October 2004. 
10. Fernandes, G.W.; Oki, Y.; Sanchez-Azofeifa, A.; Faccion, G.; Amaro-Arruda, H.C. Hail impact on leaves and endophytes of the endemic threatened Coccoloba cereifera (Polygonaceae). Plant Ecol. 2011, 212, 1687-1697. [CrossRef]

11. Gao, B.-C. NDWI-A normalized difference water index for remote sensing of vegetation liquid water from space. Remote Sens. Environ. 1996, 58, 257-266. [CrossRef]

12. Hatfield, J.L.; Prueger, J.H. Value of using different vegetative indices to quantify agricultural crop characteristics at different growth stages under varying management practices. Remote Sens. 2010, 2, 562-578. [CrossRef]

13. Merzlyak, M.N.; Gitelson, A.A.; Chivkunova, O.B.; Rakitin, V.Y. Non-destructive optical detection of pigment changes during leaf senescence and fruit ripening. Physiol. Plant. 1999, 106, 135-141. [CrossRef]

14. Sosa, L.; Justel, A.; Molina, Í. Detection of Crop Hail Damage with a Machine Learning Algorithm Using Time Series of Remote Sensing Data. Agronomy 2021, 11, 2078. [CrossRef]

15. Sarvia, F.; De Petris, S.; Borgogno-Mondino, E. A Methodological Proposal to Support Estimation of Damages from Hailstorms Based on Copernicus Sentinel 2 Data Times Series. In Proceedings of the International Conference on Computational Science and Its Applications, Cagliari, Italy, 1-4 July 2020; pp. 737-751.

16. De Leeuw, J.; Vrieling, A.; Shee, A.; Atzberger, C.; Hadgu, K.M.; Biradar, C.M.; Keah, H.; Turvey, C. The potential and uptake of remote sensing in insurance: A review. Remote Sens. 2014, 6, 10888-10912. [CrossRef]

17. Prabhakar, M.; Gopinath, K.; Reddy, A.; Thirupathi, M.; Rao, C.S. Mapping hailstorm damaged crop area using multispectral satellite data. Egypt. J. Remote Sens. Space Sci. 2019, 22, 73-79. [CrossRef]

18. Sawant, S.; Mohite, J.; Sakkan, M.; Pappula, S. Near real time crop loss estimation using remote sensing observations. In Proceedings of the 2019 8th international conference on Agro-Geoinformatics (Agro-Geoinformatics), Istanbul, Turkey, 16-19 July 2019; pp. 1-5.

19. Kuenzer, C.; Dech, S.; Wagner, W. Remote sensing time series revealing land surface dynamics: Status quo and the pathway ahead. In Remote Sensing Time Series; Springer: Cham, Switzerland, 2015; pp. 1-24.

20. Simko, I.; Piepho, H.-P. The area under the disease progress stairs: Calculation, advantage, and application. Phytopathology 2012, 102, 381-389. [CrossRef] [PubMed]

21. Zhang, T.; Vail, S.; Duddu, H.S.; Parkin, I.A.; Guo, X.; Johnson, E.N.; Shirtliffe, S.J. Phenotyping Flowering in Canola (Brassica napus L.) and Estimating Seed Yield Using an Unmanned Aerial Vehicle-Based Imagery. Front. Plant Sci. 2021, 12, 1178. [CrossRef] [PubMed]

22. Bueckert, R. Simulated hail damage and yield reduction in lentil. Can. J. Plant Sci. 2011, 91, 117-124. [CrossRef]

23. Wang, L.; Liu, Y.; Wen, M.; Li, M.; Dong, Z.; He, Z.; Cui, J.; Ma, F. Using field hyperspectral data to predict cotton yield reduction after hail damage. Comput. Electron. Agric. 2021, 190, 106400. [CrossRef]

24. Saskatchewan, M.O.A. Crop Report for the Period June 30 to July 6, 2020; Saskatchewan Government: Saskatoon, SK, Canada, 2020.

25. Canada, A. Saskatchewan Quarter Section Fabric. 2020. Available online: https://gisappl.saskatchewan.ca/Html5Ext/index. html?viewer=saskinteractive (accessed on 20 January 2021).

26. Braaten, J.M. Sentinel-2 Cloud Masking with s2cloudless. 2021. Available online: https://developers.google.com/earth-engine/ tutorials/community/sentinel-2-s2cloudless (accessed on 10 May 2021).

27. Rouse, J.W.; Haas, R.H.; Schell, J.A.; Deering, D.W. Monitoring vegetation systems in the Great Plains with ERTS. NASA Spec. Publ. 1974, 351, 309.

28. Gitelson, A.A.; Kaufman, Y.J.; Merzlyak, M.N. Use of a green channel in remote sensing of global vegetation from EOS-MODIS. Remote Sens. Environ. 1996, 58, 289-298. [CrossRef]

29. Zhou, J.; Pavek, M.J.; Shelton, S.C.; Holden, Z.J.; Sankaran, S. Aerial multispectral imaging for crop hail damage assessment in potato. Comput. Electron. Agric. 2016, 127, 406-412. [CrossRef]

30. Rahman, M.M.; Robson, A.J. A novel approach for sugarcane yield prediction using landsat time series imagery: A case study on Bundaberg region. Adv. Remote Sens. 2016, 5, 93-102. [CrossRef]

31. Qi, J.; Chehbouni, A.; Huete, A.R.; Kerr, Y.H.; Sorooshian, S. A modified soil adjusted vegetation index. Remote Sens. Environ. 1994, 48, 119-126. [CrossRef]

32. Huete, A.R. A soil-adjusted vegetation index (SAVI). Remote Sens. Environ. 1988, 25, 295-309. [CrossRef]

33. Ren, S.; Chen, X.; An, S. Assessing plant senescence reflectance index-retrieved vegetation phenology and its spatiotemporal response to climate change in the Inner Mongolian Grassland. Int. J. Biometeorol. 2017, 61, 601-612. [CrossRef] [PubMed]

34. Chen, P.-Y.; Fedosejevs, G.; Tiscareno-Lopez, M.; Arnold, J.G. Assessment of MODIS-EVI, MODIS-NDVI and VEGETATIONNDVI composite data using agricultural measurements: An example at corn fields in western Mexico. Environ. Monit. Assess. 2006, 119, 69-82. [CrossRef] [PubMed]

35. Welikhe, P.; Quansah, J.; Fall, S.; McElhenney, W. Estimation of Soil Moisture Percentage Using LANDSAT-based Moisture Stress Index. J. Remote Sens. GIS 2017, 6, 2. [CrossRef]

36. McFeeters, S.K. The use of the Normalized Difference Water Index (NDWI) in the delineation of open water features. Int. J. Remote Sens. 1996, 17, 1425-1432. [CrossRef]

37. Parmar, M.; Solanki, H.; Kalubarme, M.H. Wheat Crop Growth Monitoring using Multi-Spectral Vegetation Indices in Bhal Region, Gujarat State. Int. J. Adv. Agric. Sci. Technol. 2020, 7, 47-66.

38. Singh, K.V.; Setia, R.; Sahoo, S.; Prasad, A.; Pateriya, B. Evaluation of NDWI and MNDWI for assessment of waterlogging by integrating digital elevation model and groundwater level. Geocarto Int. 2015, 30, 650-661. [CrossRef] 
39. Huete, A.; Didan, K.; Miura, T.; Rodriguez, E.P.; Gao, X.; Ferreira, L.G. Overview of the radiometric and biophysical performance of the MODIS vegetation indices. Remote Sens. Environ. 2002, 83, 195-213. [CrossRef]

40. Rock, B.; Vogelmann, J.; Williams, D.; Vogelmann, A.; Hoshizaki, T. Remote detection of forest damage. Bioscience 1986, 36, 439-445. [CrossRef]

41. Choudhary, K.K.; Chakraborty, A.; Murthy, C.; Poddar, M.K. Satellite-Based Assessment of Hailstorm Affected Potato Crop for Insurance Purpose. 2021. Available online: https://www.researchgate.net/publication/354936404_Satellite-Based_Assessment_ of_Hailstorm_Affected_Potato_Crop_for_Insurance_Purpose (accessed on 10 November 2021).

42. Petoumenou, D.G.; Biniari, K.; Xyrafis, E.; Mavronasios, D.; Daskalakis, I.; Palliotti, A. Effects of Natural Hail on the Growth, Physiological Characteristics, Yield, and Quality of Vitis vinifera L. cv. Thompson Seedless under Mediterranean Growing Conditions. Agronomy 2019, 9, 197. [CrossRef]

43. Tartachnyk, I.; Blanke, M.; Jackson, M. Effect of hail on photosynthesis, chlorophyll fluorescence, stomatal closure and evapotranspiration of apple leaves. Acta Hortic. 2007, 732, 543-547. [CrossRef]

44. Araki, T.; Thay, O.; Kubota, F. Effects of flooding treatments on photosynthetic activity of different greengram (Vigna radiata (L.) Wilczek) cultivars. Environ. Control. Biol. 2014, 52, 1-5. [CrossRef]

45. Ceccato, P.; Flasse, S.; Tarantola, S.; Jacquemoud, S.; Grégoire, J.-M. Detecting vegetation leaf water content using reflectance in the optical domain. Remote Sens. Environ. 2001, 77, 22-33. [CrossRef]

46. Zhao, J.; Zhang, D.; Luo, J.; Huang, S.; Dong, Y.; Huang, W. Detection and mapping of hail damage to corn using domestic remotely sensed data in China. Aust. J. Crop. Sci. 2012, 6, 101-108.

47. Okeyo, S.A.; Mulaku, G.C. Crop Insurance Based on Satellite Remote Sensing: Case of Migori County, Kenya. Adv. Remote Sens. 2020, 9, 1-11. [CrossRef]

48. Larcher, W. Ecophysiology and stress physiology of functional groups. In Physiological Plant Ecology; Springer: Berlin, Germany, 1995; pp. 340-353.

49. Xu, H.; Tian, L.; Guo, R.; Lin, T.; Cui, J.; Su, X.; Kong, J.; Zhu, J. Hail disaster and remedial measures of post disaster cotton field management in South Xinjiang. In Proceedings of the China Cotton Society in 2015, Xinjiang, China, 9-11 August 2015; pp. 163-165.

50. Molthan, A.L.; Burks, J.E.; Mcgrath, K.M.; Lafontaine, F.J. Multi-Sensor Examination of Hail Damage Swaths for Near Real-Time Applications and Assessment. J. Oper. Meteorol. 2013, 1, 144-156. [CrossRef]

51. Gobbo, S.; Ghiraldini, A.; Dramis, A.; Dal Ferro, N.; Morari, F. Estimation of Hail Damage Using Crop Models and Remote Sensing. Remote Sens. 2021, 13, 2655. [CrossRef] 